\title{
EFFECT OF UPPER DECK TEMPERATURE ON THE HEALTH OF MEN IN SHIPS OF THE ROYAL NAVY \\ BY
}

\author{
F. P. ELLIS \\ Medical Research Council: Royal Naval Tropical Research Unit, Singapore
}

AND

F. E. SMITH and C. R. UNDERWOOD

Environmental Hygiene Research Unit, London

There have been several attempts in recent years to relate the incidence of sickness in the Royal Navy to variations of the thermal environment of ships' companies. During the second world war the incidence of the common causes of ill health, as revealed by attendances at the sick bay, was shown to be nearly twice as great in the ships of the Eastern and British Pacific Fleets as it was in shore establishments, where the mean air temperature was usually about $7^{\circ} \mathrm{F}$. lower than the temperature between decks; this difference was due largely to an increase in the incidence of skin disease (Ellis, 1947, 1948). Time lost due to sickness was doubled or trebled when ships joined the Eastern Fleet from the Mediterranean or Home Fleets.

When the war ended, relaxation of security precautions concerning the movement of warships made it possible for such information to be included in the monthly returns of sickness to the Admiralty. These returns revealed that during the first year after the war the relative sickness incidence was more than doubled in tropical waters as contrasted with northern temperate waters, and diseases of the skin were increased by three to four times (Roberts, 1948).

Recent work suggests that for different classes of ships it may be possible to predict the mean messdeck temperature with reasonable accuracy provided the mean upper deck temperature is known (Gray and Smith, 1952). In this event it may be possible to relate sickness to the average thermal environment between decks more accurately than has been possible hitherto. In 1948 it was requested that the mean upper deck temperature at noon should be included with each monthly return. The results of the analysis of the returns including this information for the year October 1, 1948, to September 30, 1949, are described below.

\section{Methods}

Medical officers in charge of ships reported the numbers on the attending lists and sick lists at midnight each Wednesday and also the numbers who had been sent to hospital during the previous week. The total number of cases on the sick and attending lists was subdivided into (a) respiratory infections, (b) dysentery and diarrhoea, (c) skin disorders, $(d)$ all other diseases, and (e) injuries and accidents. The average weekly air temperature on the upper deck at noon was included with each weekly report together with information on the whereabouts of the ship. These particulars were supplied in accordance with the detailed instructions reproduced below:

(2) The return is to be rendered only by ships carrying a medical officer; medical officers in parent ships are to make returns for their parent ship only and not for personnel in tenders.

(3) The fixed time each week to which the count will refer is at 23.59 on each Wednesday. The returns are to be made each calendar month and will include four or five weekly counts, depending upon how many Wednesdays there are in the particular calendar month. The figures for the last Wednesday of the previous calendar month are also to be included, so that the rate for the first weekly period can be worked out. Nil returns are to be made. Immediately after the last count of the calendar month, one copy of the return is to be forwarded to the Medical Director General, Admiralty, and one copy to the Fleet Medical Officer.

(4) The average complement is to be given for each week, and in calculating complement and number of cases, both officers and ratings are to be included together.

(5) The count of Sick List cases (with Excused Duty List cases) is to include all those who are excused duty as at 23.59 on the Wednesday in question.

(6) For the purposes of this return a patient is to be regarded as being on the Attending List when he attends at the sick bay and is instructed to report again within a period not exceeding a fortnight. Single visits with no instruction to return are not to be included. If the patient is told that he need not attend again, or not within a period of a fortnight, he is no longer to be shown in the return. No distinction is to be made between those on light duty and those on full duty.

(7) The few broad disease groups chosen are designed particularly for investigating habitability, and the effect of differences in climate. "Upper Respiratory Infections" should include infections of the nose, sinuses, nasopharynx, larynx, and trachea, including influenza, colds, sore throats, and Vincent's infection; it should not include diseases of the bronchi and lungs. "Diseases of the Skin" should include boils, otitis externa, tropical ulcers, and 
mycotic infections. Scabies and pediculosis should be included with "All Other Diseases" and not under "Diseases of the Skin".

As in the certification of deaths, serious disease following a very trivial injury should be classified as disease and not as injury, e.g. septicaemia following a scratch, and all tropical ulcers. Illness due to noxious agents, bites or stings, attempted suicide, or extremes of physical conditions, e.g. heat stroke or frostbite, should be classified as injury.

(8) There must be no duplication of cases, i.e. one and the same man can only appear once in the weekly count. If he is suffering from more than one illness and could be included under more than one disease heading, the medical officer is to decide on a primary diagnosis and the man should be so classified. THE SICK LIST TAKES PRECEDENCE OVER THE ATTENDING LIST. For example, if a man "returned" as on the Attending List at a given Wednesday midnight owing to a skin condition, subsequently develops a cold and is on the Sick List at midnight the following Wednesday, he should be shown in the second Wednesday's count under "Sick List-Upper Respiratory Infections". If by the third Wednesday he has been discharged from the Sick List but remains on the Attending List owing to his skin condition he will once again appear under "Attending List-Skin Diseases" in the count for the third Wednesday. If a man is on the Sick or. Attending List for more than one disease, the medical officer should decide on the primary diagnosis.

(9) Cases of venereal disease are not to be included in the return.

(10) In view of the possible differences of procedures regarding discharge from the ships' books of those sent to hospital, it is not possible to make a simple count of men in hospital as at 23.59 each Wednesday. Instead, the figure (unlike those of the Sick and Attending Lists) will refer to the number of cases discharged to hospital during the week ending at 23.59 on Wednesday. Hospital cases will be shown in total only.

(11) The position and movements of the ship during the period of the return are to be included in the space provided. It will be appreciated that what is required is a full resume with dates. What is important is whether the ship is (a) in port and, if so, in what ports; $(b)$ at sea, and in approximately what waters.

Periods in port can easily be recorded with names and dates. If the ship is proceeding to sea daily for exercises it will be sufficient to mention that fact in all brevity. Voyages other than those direct from port to port will require more detailed particulars.

(12) In the space for remarks should be included information concerning any special circumstances which might have had an effect on the figures, e.g. epidemics, serious accidents, prevalent diseases ashore, leave, etc.

Thus the percentages of men on the Sick and Attending Lists were based on weekly census counts taken at midnight on each Wednesday. A given week runs from Wednesday midnight to Wednesday midnight and the figures for that week are estimated by averaging the figures at the beginning and the end. This does not provide information on case incidence or on the duration of individual sicknesses; the measure which is obtained is simply the percentage of the ship's company who are sick. This is a constantly fluctuating figure, but experience has shown, for example in the short term sickness returns of the United States Army (1952), that the mean of the census counts at the beginning and end of each week provides sufficiently accurate information for all practical purposes.

The admission of men to hospital cannot, for a variety of reasons, be dealt with by a cenus method. Hospital admissions are included to complete the record, though the numbers are normally small.

The most impressive effects of climatic change are found in the size of the attending lists. It is therefore important to note that the instructions relating to the returns on which this report and the earlier one by Roberts are based state that a man should only be shown as on the Attending List if he has been instructed to return again for treatment within a fortnight. Thus single attendances for conditions of trivial importance, and many skin conditions aggravated by warm climates fall into this category, would not be shown and would not contribute to the sickness incidence reported below.

The units employed in the construction of the Tables and Figures are the average monthly percentages; the months being periods of four or five weeks and not calendar months.

\section{RESULTS}

During the year under consideration sickness returns which were suitable for analysis were received from 77 ships, and as each ship rendered on the average just over eight monthly returns there were 282,000 man-months available for analysis; rather less than the $1,600,000$ man-weeks which were available to Roberts (1948) for the first year aft the war ended.

The number of man-months available for examt nation in relation to the prevailing upper deck temperatures is slightly less than the number available for examination in relation to the station on which ships were at the time, because in some instances, although the station was noted on the return, the temperatures were either not included or were obviously faulty.

SICKNESS INCIDENCE AND UPPER DECK TEMPERATURE.-The data were analysed to show the effects ? of variations in the mean upper deck temperature $\overline{3}$ on the percentages in the attending and sick lists, and on the numbers of men sent to hospital in the 0 previous week. These relationships for all classes

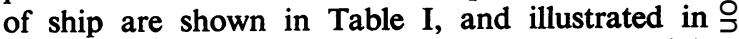
Fig. 1. There was very little change in the sick $D$ list incidence whatever the upper deck temperature, but the attending list increased gradually as the $\bar{N}$ average weekly noon upper deck temperature rose. When the temperature rose above $80^{\circ} \mathrm{F}$. there was a $\mathrm{N}$ steeper rise in the attending list, and when the mean $\mathrm{N}$ upper deck temperature exceeded $90^{\circ} \mathrm{F}$. the increase was very striking.

Ships do not spend very much time in parts of the world where the mean noon temperature exceeds $90^{\circ} \mathrm{F}$. The average number of weeks during which ${ }^{0}$ 
TABLE I

MEAN WEEKLY SICKNESS INCIDENCE (PER CENT.) FOR ALL SHIPS IN RELATION TO VARIATIONS IN MEAN WEEKLY NOON UPPER DECK TEMPERATURE

\begin{tabular}{|c|c|c|c|c|c|c|c|c|c|c|c|c|c|c|c|c|}
\hline \multicolumn{2}{|c|}{ Dry Bulb Temperature $\left({ }^{\circ} \mathrm{F}.\right)$} & $34-9$ & $35 \cdot 9$ & $\begin{array}{l}40- \\
44 \cdot 9\end{array}$ & $\begin{array}{c}45- \\
49 \cdot 9\end{array}$ & $\begin{array}{l}50- \\
54 \cdot 9\end{array}$ & $\begin{array}{c}55- \\
59 \cdot 9\end{array}$ & $\begin{array}{l}60- \\
64 \cdot 9\end{array}$ & $\begin{array}{l}65- \\
69 \cdot 9\end{array}$ & $\begin{array}{l}70- \\
74 \cdot 9\end{array}$ & $\begin{array}{c}75- \\
79 \cdot 9\end{array}$ & $\begin{array}{l}80- \\
84 \cdot 9\end{array}$ & $\begin{array}{l}85- \\
89 \cdot 9\end{array}$ & $\begin{array}{l}90 \\
94 \cdot 9\end{array}$ & $\begin{array}{l}95- \\
99 \cdot 9\end{array}$ & Mean \\
\hline \multicolumn{2}{|c|}{ No. of Ship-months (Total 641) } & 2 & 2 & 10 & 49 & 67 & 94 & 59 & 82 & 68 & 63 & 88 & 50 & 6 & 1 & \\
\hline \multirow{6}{*}{$\begin{array}{l}\text { Attend- } \\
\text { ing } \\
\end{array}$} & $\begin{array}{c}\text { Upper respiratory } \\
\text { infections }\end{array}$ & 0.55 & 0.61 & 0.53 & $0 \cdot 84$ & 0.45 & 0.45 & 0.53 & 0.44 & 0.44 & $0 \cdot 30$ & $0 \cdot 50$ & 0.46 & $0 \cdot 83$ & 0.07 & $0 \cdot 50$ \\
\hline & $\begin{array}{c}\text { Dysenteries and } \\
\text { diarrhoea }\end{array}$ & $0 \cdot 11$ & 0.04 & 0.05 & 0.07 & 0.08 & 0.08 & 0.08 & 0.08 & $0 \cdot 12$ & $0 \cdot 23$ & $0 \cdot 15$ & $0 \cdot 11$ & 0.61 & 0.00 & $0 \cdot 11$ \\
\hline & Skin diseases & 0.95 & $1 \cdot 21$ & $0 \cdot 75$ & $\overline{0.82}$ & 0.94 & $1 \cdot 29$ & $1 \cdot 40$ & $1 \cdot 59$ & 1.42 & $1 \cdot 81$ & $2 \cdot 57$ & $2 \cdot 17$ & $4 \cdot 22$ & 1.62 & $1 \cdot 60$ \\
\hline & Injuries and accidents & 0.61 & 0.45 & 0.56 & 0.65 & $0 \cdot 58$ & $0 \cdot 77$ & 0.94 & $0 \cdot 76$ & 0.86 & 0.73 & 0.85 & 0.63 & $2 \cdot 36$ & 0.00 & $0 \cdot 77$ \\
\hline & All other diseases & $1 \cdot 14$ & $1 \cdot 06$ & $1 \cdot 23$ & 0.93 & $0 \cdot 78$ & $1 \cdot 11$ & $1 \cdot 16$ & $1 \cdot 10$ & $1 \cdot 13$ & $1 \cdot 13$ & $1 \cdot 51$ & $1 \cdot 44$ & $3 \cdot 55$ & $3 \cdot 17$ & $1 \cdot 17$ \\
\hline & Total . & $3 \cdot 36$ & $3 \cdot 37$ & $3 \cdot 12$ & $3 \cdot 31$ & $2 \cdot 83$ & $3 \cdot 70$ & $4 \cdot 11$ & $3 \cdot 97$ & $3 \cdot 97$ & $4 \cdot 20$ & $5 \cdot 58$ & $4 \cdot 81$ & $11 \cdot 57$ & $4 \cdot 86$ & $4 \cdot 15$ \\
\hline \multirow{6}{*}{ Sick } & $\begin{array}{c}\text { Upper respiratory } \\
\text { infections }\end{array}$ & $0 \cdot 29$ & 0.05 & 0.32 & $0 \cdot 28$ & $0 \cdot 22$ & $0 \cdot 19$ & $0 \cdot 14$ & 0.13 & $0 \cdot 13$ & 0.09 & 0.08 & $0 \cdot 10$ & $0 \cdot 21$ & 0.00 & $0 \cdot 15$ \\
\hline & $\begin{array}{c}\text { Dysenteries and } \\
\text { diarrhoea }\end{array}$ & 0.02 & 0.01 & 0.01 & 0.01 & 0.02 & 0.01 & 0.01 & 0.03 & 0.03 & 0.07 & 0.05 & 0.05 & 0.06 & 0.00 & 0.03 \\
\hline & Skin diseases & 0.07 & 0.02 & 0.05 & 0.05 & 0.07 & $\overline{0 \cdot 11}$ & 0.08 & $0 \cdot 10$ & $0 \cdot 11$ & $0 \cdot 12$ & $0 \cdot 15$ & $0 \cdot 12$ & 0.07 & 0.00 & $0 \cdot 10$ \\
\hline & Injuries and accidents & 0.03 & 0.05 & $0 \cdot 10$ & 0.08 & $0 \cdot 12$ & $0 \cdot 10$ & $0 \cdot 12$ & $0 \cdot 10$ & $0 \cdot 14$ & 0.08 & $0 \cdot 10$ & $0 \cdot 11$ & $0 \cdot 14$ & 0.00 & $0 \cdot 10$ \\
\hline & All other diseases & $0 \cdot 12$ & 0.08 & 0.43 & $\overline{0 \cdot 20}$ & $\overline{0 \cdot 13}$ & $0 \cdot 21$ & $0 \cdot 17$ & $0 \cdot 18$ & $0 \cdot 28$ & $\overline{0 \cdot 18}$ & $0 \cdot 20$ & $0 \cdot 24$ & $0 \cdot 28$ & $\overline{0.00}$ & 0.20 \\
\hline & Total .. & 0.53 & $0 \cdot 21$ & 0.91 & 0.62 & 0.56 & 0.62 & 0.52 & 0.54 & 0.69 & $0 \cdot 54$ & 0.58 & 0.62 & 0.76 & 0.00 & 0.58 \\
\hline \multicolumn{2}{|c|}{ Total Sent to Hospital } & $0 \cdot 16$ & 0.15 & 0.27 & $0 \cdot 24$ & 0.35 & 0.26 & 0.24 & $0 \cdot 31$ & 0.24 & $0 \cdot 19$ & 0.32 & $0 \cdot 37$ & $\overline{0 \cdot 19}$ & $\overline{0.00}$ & $0 \cdot 27$ \\
\hline
\end{tabular}

the ships rendering these returns were exposed to the different ranges of temperature are illustrated in Fig. 2. The high incidence which occurred when the mean temperature was above $90^{\circ} \mathrm{F}$. thus refers to a very small number of the ships and to short periods. The section of the Fleet studied here77 ships - was exposed to mean noon temperatures ranging between $50^{\circ}$ and $60^{\circ} \mathrm{F}$., $60^{\circ}$ and $70^{\circ} \mathrm{F}$., $70^{\circ}$ and $80^{\circ} \mathrm{F}$., and $80^{\circ}$ and $90^{\circ} \mathrm{F}$., for about 12 weeks each on the average during the year.

The climatic conditions to which the different classes of ship were exposed during the year also varied considerably. The main battleship and aircraft carrier force was in Home Waters or in the Mediterranean and the mean noon upper deck temperature for the year for each of these groups

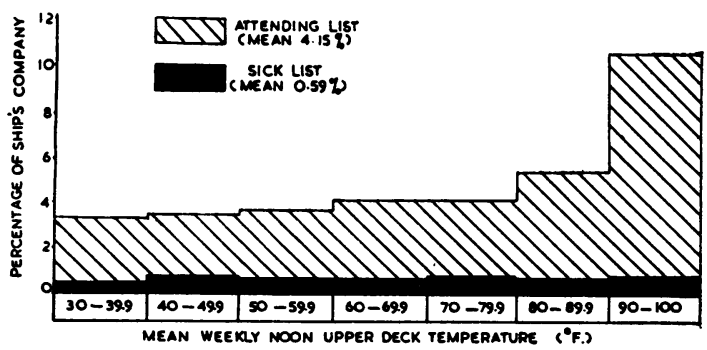

FIG. 1.-Average percentage (for 77 ships) of ship's company on attending and sick lists related to mean weekly upper deck temperature at noon. was $60^{\circ} \mathrm{F}$; but for the cruisers, destroyers, sloops, and frigates which spent more time in tropical and sub-tropical waters; the corresponding mean temperatures were $68^{\circ}, 70^{\circ}, 73^{\circ}$, and $74^{\circ} \mathrm{F}$. respectively. Information on the effects of the warmer climatic conditions thus relates to men serving in small ships to a greater extent than to men serving in large ships.

"Skin Diseases" and "All Other Diseases" (Fig. 3 overleaf) contribute more than the other groups to the rise in the attending list under the warmer climatic conditions. A rise in the rate for injuries and accidents also occurred when the mean upper deck temperature was above $90^{\circ} \mathrm{F}$., although then the numbers were small (7 ship-months). Sickness due to the dysenteries and diarrhoea and to

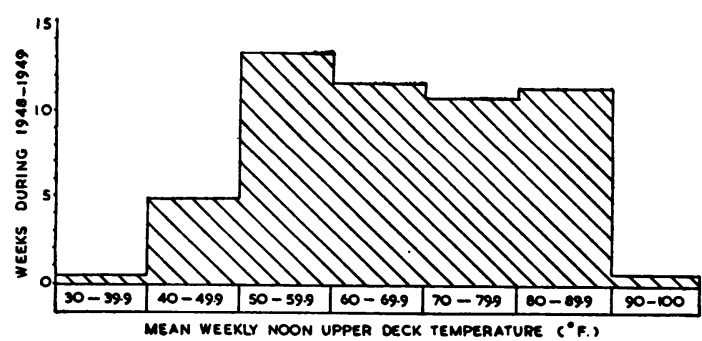

Fig. 2.-Number of weeks in the year 1948-49 for which the 77 ships under investigation were exposed to mean upper deck temperatures at noon ranging between $30^{\circ}$ and $100^{\circ} \mathrm{F}$. 


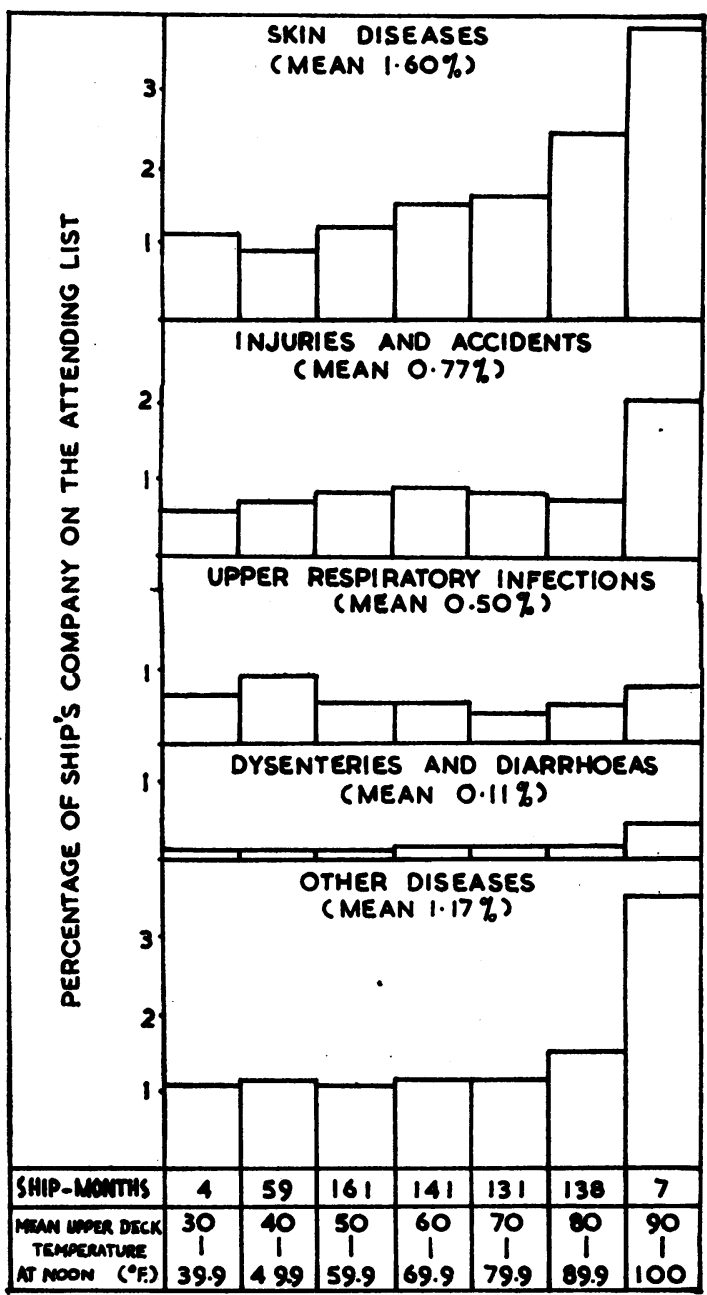

FIG 3.-Average percentage (for 77 ships) of ship's company on attending list with complaints in the five main disease groups related to mean upper deck temperature at noon.

respiratory illnesses was unaffected by increases in the average air temperature. It would be interesting to know which of the "other diseases" were chiefly responsible for the increase in the attending list.

SiCKNESS INCIDENCE AND Class of SHIP.-The data relating to "skin diseases" were re-examined to determine whether the incidence varied between large ships such as battleships, aircraft carriers, or cruisers, small ships such as destroyers, frigates, sloops, and minesweepers, or miscellaneous ships such as depot or repair ships. The results are shown in Fig. 4 (opposite). The incidence of skin disease in sloops and cruisers was more affected by the mean upper deck temperature rising above $80^{\circ} \mathrm{F}$. than that in frigates and destroyers, but an upward trend is present for all classes of ship for which adequate relevant data are available when the 8 temperature rose above $80^{\circ} \mathrm{F}$. When the mean 3 noon temperature on the upper deck exceeded $80^{\circ} \mathrm{F}$., $\stackrel{\mathbb{8}}{\stackrel{\circ}{2}}$ data were available for only 1 ship-month for battleships, 3 ship-months for aircraft carriers, $\stackrel{\vec{S}}{\rightarrow}$ and 4 ship-months for depot ships. Thus on the average the men in these classes of ship may have been less accustomed to warm climates than the men in the smaller classes of ship, and more likely to succumb to minor climatic illnesses.

Evidence on the health of men serving in different classes of ship in warm climates in wartime was obtained from the Eastern Fleet in 1944. The sickness rates were calculated for the common causes of ill health. These showed that depot ships and repair ships were the least healthy, with a mean reporting rate of 29 per 100 man-months: 29 out of every 100 men serving in these ships were entered on the sick or attending lists each month. Battleships and escort carriers were next, with rates of 26 and 25, and small ships and cruisers were the most healthy, each with 17 per 100 man-months. Roberts (1948) also found that depot and repair ships were the least healthy in hot weather during 1945-46, but that there were no differences between the other classes of ship.

Sickness InCIDENCE AND Station.-The total data were examined to determine whether service on different stations affected the health of the peacetime Navy. The main findings are given in Table II (opposite).

The Malayan area is the least healthy, according to these criteria, with total incidences on the attending list and sick list of 7.4 per cent. and $1 \cdot 1$ per cent. respectively. The China, East Indies, and Persian Gulf Stations are next on the list with 5.5 and 0.5 per cent., 5.5 and 0.5 per cent., and 5.2 and 0.45 per cent. respectively. Skin diseases account very largely for the high position of the Malayan area in this list. The Home Fleet and Mediterranean Fleet were almost equally healthy during this period, with attending and sick list incidences of $3 \cdot 14$ and 0.77 per cent., and 3.24 and 0.49 per cent.

The average noon upper deck temperature for the period under examination is given for each station. The Malayan area is the most unhealthy and according to these figures it is also the warmest. But although the average mid-day temperature is much higher on the East Indies Station than on the China Station, the incidences of sickness on the two stations are similar. Thus factors other than the climate may be involved. 


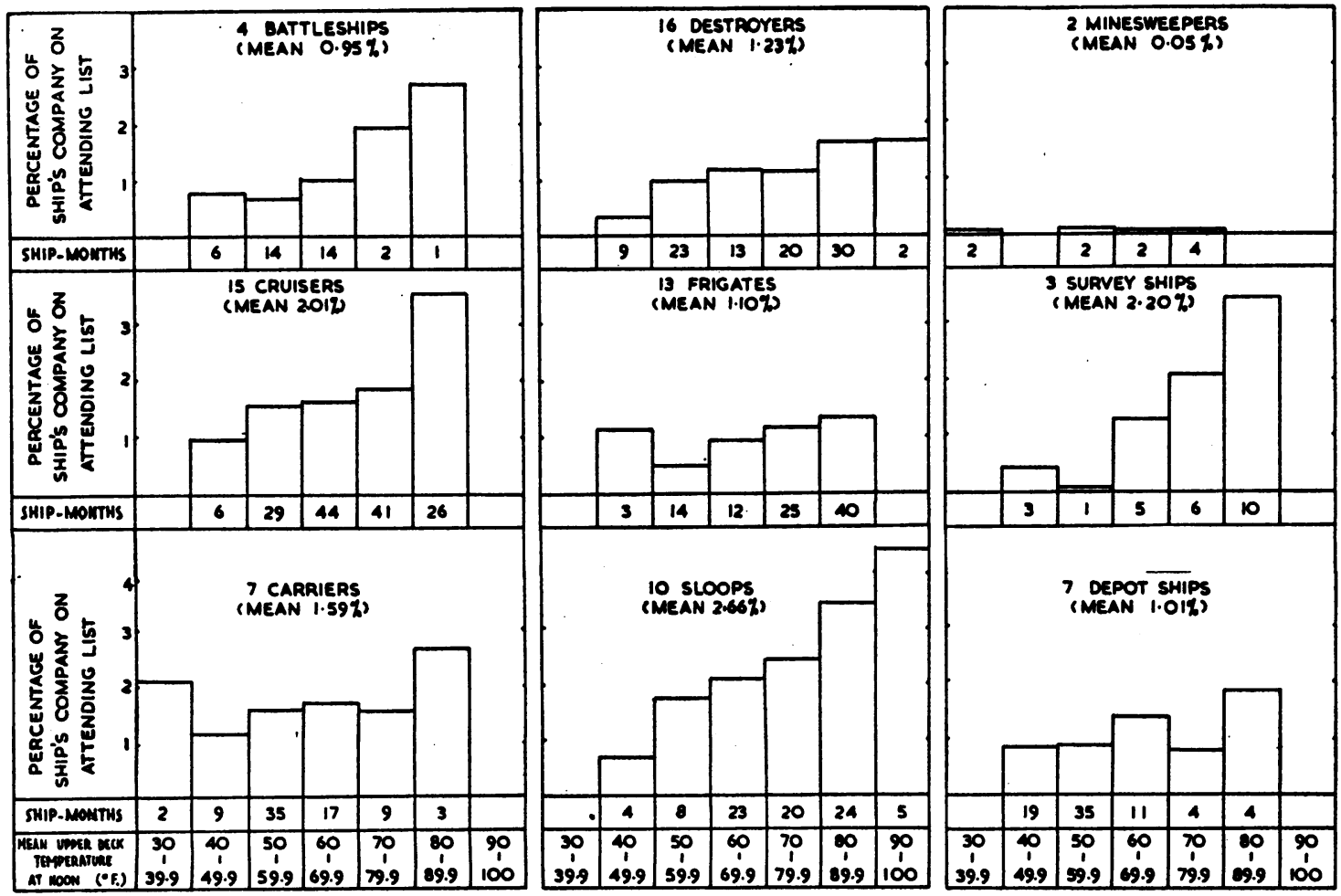

FiG. 4.-Average percentage of ship's company on attending list with skin disease for the nine different classes of ship related to mean upper deck temperature at noon.

TABLE II

MEAN WEEKLY SICKNESS INCIDENCE (PER CENT.) FOR ALL SHIPS ON DIFFERENT STATIONS

\begin{tabular}{|c|c|c|c|c|c|c|c|c|c|c|c|}
\hline Station & . & . & China & Malaya & $\begin{array}{l}\text { East } \\
\text { Indies }\end{array}$ & $\begin{array}{l}\text { West } \\
\text { Indies }\end{array}$ & $\begin{array}{l}\text { Medi- } \\
\text { terranean }\end{array}$ & $\begin{array}{l}\text { Persian } \\
\text { Gulf }\end{array}$ & Home & $\begin{array}{l}\text { Miscel- } \\
\text { laneous }\end{array}$ & Mean \\
\hline \multicolumn{3}{|c|}{ No. of Ship-months (Total 652) } & 95 & 50 & 15 & 48 & 148 & 30 & 195 & 71 & \\
\hline \multicolumn{3}{|c|}{$\begin{array}{c}\text { Mean weekly noon upper deck } \\
\text { temperatue }\left({ }^{\circ} \mathrm{F} .\right) \quad \ldots\end{array}$} & $72 \cdot 4$ & $84 \cdot 0$ & $83 \cdot 2$ & $76 \cdot 9$ & $67 \cdot 6$ & $77 \cdot 2$ & $54 \cdot 5$ & $68 \cdot 6$ & $62 \cdot 8$ \\
\hline \multirow{6}{*}{$\begin{array}{c}\text { Attend- } \\
\text { ing }\end{array}$} & $\begin{array}{l}\text { Upper respiratory } \\
\text { infections } \ldots\end{array}$ & $\ldots$ & 0.64 & 0.55 & $0 \cdot 15$ & 0.45 & $0 \cdot 31$ & 0.71 & 0.53 & 0.48 & 0.48 \\
\hline & $\begin{array}{l}\text { Dysenteries and } \\
\text { diarrhoea ... }\end{array}$ & $\therefore$ & $0 \cdot 17$ & 0.82 & $0 \cdot 10$ & 0.08 & 0.11 & $0 \cdot 22$ & 0.07 & 0.15 & $0 \cdot 11$ \\
\hline & Skin diseases .. & $\ldots$ & $2 \cdot 11$ & $3 \cdot 23$ & $2 \cdot 45$ & $1 \cdot 76$ & $1 \cdot 27$ & $2 \cdot 09$ & 0.96 & $1 \cdot 71$ & $1 \cdot 61$ \\
\hline & Injuries and acciden & & $1 \cdot 08$ & 0.86 & 0.73 & 1.05 & 0.57 & 0.91 & 0.63 & 0.95 & 0.77 \\
\hline & All other diseases & .. & 1.49 & 1.91 & $2 \cdot 10$ & 1.45 & 0.98 & $1 \cdot 29$ & 0.95 & $1 \cdot 16$ & $1 \cdot 18$ \\
\hline & Total & .. & $5 \cdot 49$ & $7 \cdot 37$ & $5 \cdot 53$ & $4 \cdot 79$ & $3 \cdot 24$ & $5 \cdot 22$ & $3 \cdot 14$ & $4 \cdot 45$ & $4 \cdot 15$ \\
\hline \multirow[t]{2}{*}{. } & $\begin{array}{l}\text { Upper respiratory } \\
\text { infections } \ldots\end{array}$ & .. & 0.09 & 0.09 & 0.03 & $0 \cdot 15$ & $0 \cdot 12$ & 0.11 & 0.41 & 0.21 & $0 \cdot 15$ \\
\hline & $\begin{array}{l}\text { Dysenteries and } \\
\text { diarrhoea } \ldots\end{array}$ & .. & 0.05 & 0.32 & 0.06 & 0.02 & 0.04 & 0.04 & 0.02 & 0.05 & 0.03 \\
\hline \multirow{4}{*}{ Sick } & Skin diseases ... & . & 0.07 & $0 \cdot 25$ & $0 \cdot 12$ & 0.12 & 0.08 & 0.05 & 0.07 & $0 \cdot 15$ & $0 \cdot 11$ \\
\hline & Injuries and acciden & & $0 \cdot 12$ & 0.15 & 0.09 & 0.11 & 0.09 & 0.09 & 0.09 & 0.13 & $0 \cdot 10$ \\
\hline & All other diseases & $\ldots$ & 0.21 & $0 \cdot 30$ & $0 \cdot 22$ & 0.28 & $0 \cdot 16$ & $0 \cdot 16$ & 0.18 & $0 \cdot 19$ & 0.20 \\
\hline & Total & $\ldots$ & 0.54 & $1 \cdot 11$ & 0.52 & 0.68 & 0.49 & 0.45 & 0.77 & 0.73 & 0.59 \\
\hline \multicolumn{2}{|c|}{ Total Sent to Hospital } & $\ldots$ & 0.44 & $0 \cdot 27$ & $0 \cdot 27$ & 0.17 & 0.26 & 0.09 & $0 \cdot 32$ & 0.24 & 0.27 \\
\hline
\end{tabular}




\section{Discussion}

The aim of this investigation was to determine the relationship between the average noon upper deck temperature and the incidence of sickness in ships of the Fleet serving in different parts of the world, estimated from the numbers of cases on the attending lists or sick lists at midnight each Wednesday (not from the total case incidence). The data examined relate to peace-time and not to war-time or the immediately post-war period. Variations in the deployment of ships in different parts of the world, the composition of ships' companies, the strength of the naval force, and operational conditions which influence habitability (such as "blackout" and damage control precautions) prevent the direct comparison of these results with those of earlier studies.

The analysis confirms the finding of war-time and post-war investigations that minor ill-health is greater in ships on tropical or sub-tropical stations than in temperate or northerly waters, but the sparseness of the data available for periods when ships were exposed to hot or cold climatic extremes reveals a need for supplementing the interim conclusions recorded here when the analysis of the returns for subsequent years is available.

The sharp rise in sickness incidence when the mean monthly upper deck mid-day temperature exceeds $80^{\circ} \mathrm{F}$. points to the critical levels of warmth which limit a healthy existence afloat. The atmospheric humidity at sea is always high and except in certain machinery compartments or air-conditioned spaces the climate between decks is warm and humid. An air temperature of $80^{\circ} \mathrm{F}$. is not uncomfortable for lightly-clothed persons in the tropics, but when this temperature prevails on the upper deck that of the mess-decks is likely to be $6^{\circ}$ or $7^{\circ} \mathrm{F}$. higher, and yet greater heat will be experienced in many compartments. In a warm humid climate this makes all the difference between a reasonably comfortable thermal environment and one in which the very great majority of people are uncomfortable (Ellis, 1952). This increase in discomfort between decks is associated with an increase in skin diseases and minor ill health.

The greater prevalence of skin diseases amongst ships' companies in the Malayan area than amongst those in the Persian Gulf or on the China Station suggests that a constantly warm humid atmosphere has a more adverse effect on the annual incidence of skin diseases than the diurnal and seasonal cool and warm climatic conditions which pertain on the other stations, although this might be qualified by the fact that in recent years there has been a large increase in the installation of air-conditioning machinery in Persian Gulf ships. The position might have been different a few years ago.

The information on the illnesses which are sensitive to changes in climate-"skin disease" and "all other diseases" - could be amplified with profit. The incidence of the common causes of ill health in the Eastern Fleet when based on Trincomalee in 1944, excluding uncomplicated prickly heat which was very common in many ships, is summarized in Table III.

\section{TABLE III}

COMMON CAUSES OF ILL HEALTH IN THE EASTERN FLEET IN 1944 AS SHOWN BY ATTENDANCES AT THE SICK BAY

(Case Incidence per 100 Man-months)

\begin{tabular}{|c|c|c|c|c|}
\hline $\begin{array}{l}\text { Minor injuries } \\
\text { Other skin diseases } \\
\text { Boils . . . } \\
\text { Dysentery . . } \\
\text { Otitis externa } \\
\text { Epidermophytosis . . } \\
\text { Tinea cruris } \\
\text { Common cold } \\
\text { Sore throat. . }\end{array}$ & $\begin{array}{l}4 \cdot 20 \\
3 \cdot 25 \\
2 \cdot 64 \\
2 \cdot 63 \\
2 \cdot 05 \\
1 \cdot 91 \\
1 \cdot 86 \\
1 \cdot 56 \\
0 \cdot 81\end{array}$ & $\begin{array}{l}\text { Impetigo } \\
\text { Heat exhaustion. . } \\
\text { Dyspepsia } \\
\text { Bronchitis } \\
\text { Chronic ulcers . . } \\
\text { Pyrexia of unknow } \\
\text { Malaria . } \\
\begin{array}{l}\text { Dermatitis } \\
\text { Psychoneurosis . . }\end{array}\end{array}$ & $\begin{array}{l}\ldots \\
\cdots \\
\cdots \\
\cdots \\
\text { igin } \\
\cdots \\
\cdots\end{array}$ & $\begin{array}{l}0.45 \\
0.42 \\
0.25 \\
0.24 \\
0.19 \\
0.11 \\
0.08 \\
0.08 \\
0.06\end{array}$ \\
\hline
\end{tabular}

This shows that boils, fungus infections, otitis externa, and "other skin diseases", comprising septic skin conditions in the main, were responsible for the bulk of the skin diseases. The incidence of minor injuries was also high. Common diseases in the Eastern Fleet, which were not included if the above list but which caused a considerablê. morbidity, were prickly heat, dengue fever, and infective hepatitis. Venereal diseases, which might account for an increased sickness incidence on some tropical stations, were not included. Thus it would appear from Fig. 3 that "all other diseases" comprises certain conditions sensitive to heat, other than skin diseases and injuries, which at present cannot be identified. The instructions governing future returns might be modified to ask medical officers to include figures for the three or four main sub-groups of "all other diseases", in order to give more information on its make-up.

There is little precise information about the effects of living in a hot climate for a long time on naval health. War-time experience was that minor sickness increased markedly during the first 2 months after ships arrived on a tropical station and then declined to a rather lower level, that it was greater during the warmer seasons, and that it was more prominent during the second year of a tropical commission than the first year. The examination of data, covering the year August 1945-July 1946, showed a sharp rise in the Attending List figures in individual ships after 2 weeks in the tropics and this appeared to reach a maximum after 8 weeks; conversely, in going from the tropics to temperate waters, the 
figure fell to normal by the third week (Roberts, 1948).

More evidence of this character would assist discussions on the desirable length of a tropical commission afloat in peace-time; it could be obtained if the current monthly return was supplemented by a statement of the length of time a ship had been in commission in the tropics at the time the return was rendered.

\section{SUMMARY}

The incidence of sickness in ships of the Royal Navy during the year October 1, 1948, to September 30, 1949, has been estimated from weekly census counts rendered each month to the Admiralty. This incidence is related to the mean mid-day upper deck temperature.

The percentage of men on the sick list and the numbers sent to hospital did not vary much with changes in the upper deck temperature, but the percentage of men on the attending list increased steadily as the upper deck temperature became warmer, more markedly when it exceeded $80^{\circ} \mathrm{F}$., and very markedly when it exceeded $90^{\circ} \mathrm{F}$.
The increase in minor ill health at the higher temperatures was largely due to skin diseases, and, when the mean upper deck temperature was above $90^{\circ} \mathrm{F}$.', to injuries, also. The incidence of skin diseases thus affords a useful guide to the effect of undesirably warm humid climates on health.

When total sickness was considered in relation to the stations from which the reports were rendered, the highest incidence was found to occur in the Malayan area, with those for ships on the China and East Indies Stations and in the Persian Gulf following in that order. The lowest incidence occurred in the Home Fleet, but it differed little from that in the Mediterranean Fleets.

We wish to acknowledge the helpful advice and criticism of Dr. J. A. Fraser Roberts.

\section{REFERENCES}

Ellis, F. P. (1947). Brit. med. Bull., 5, 13. (1948). Brit. med. J., 1, 587.

(1952). J. Hyg., Camb., $50,415$.

Gray, J. A. B., and Smith, F.E. (1952). Proceedings of the Institution of Naval Architects, 94, 223 .

Roberts, J. A. F. (1948). British Journal of Social Medicine, 2, 55.

U.S. Army Progress Report (1952). "Health of the Army". 11B. August. 